\title{
Legal aspects of health implications caused by environmental distress
}

\author{
RAJKO KNEZ
}

\begin{abstract}
The article tries to explore legal consequences in cases where the environmental distress causes health implications for individuals. The author begins with the observations from two different angles, that is ex ante and ex post actions. Both approaches differ substantively, since the ex ante approach is applied by state authorities (command-and-control approach, de iure imperii acts), while the ex post approach is by a general rule initiated by individuals against polluters/state. Both approaches are discussed considering the application of EU rules and beyond (ECHR, Aarhus convention). The main emphasis is given to one of the biggest problems, that is the issue of causality, which discourages many plaintiffs from claiming damages. For the so-called post-industrial risks the conventional rules of causality do not suffice, which is why certain courts proposed that changes in this respect are necessary. In addition, the role of NGOs is emphasised, since the NGO can, especially in the ex ante approach, achieve better effects, especially when locus standi is assured.
\end{abstract}

Keywords: • environmental protection $\bullet$ healthy living environment - legal remedies in environmental law • ECHR Art. 8 - ECHR Art. 2 • command-and-control approach $\bullet$ claims for damages $\bullet$ health

Correspondence Address: Rajko Knez, Ph.D., Full Professor, University of Maribor, Faculty of Law, Mladinska ulica 9, 2000 Maribor, Slovenia, email: rajko.knez@um.si.

DOI 10.18690/24637955.10.1.33-51(2017) ISSN 2463-7955

(C) 2017 University of Maribor Press

Available at http://journals.um.si/ 
The environment and environmental protection have only recently become a concern of the international community. After the Second World War, the reconstruction of the economy and lasting peace were the priorities; these included the guarantee of civil and political as well as social and economic human rights. In these circumstances, a care for the environment and hence a care for the healthy living environment for humans and animals were not in the foreground. Neither the world community nor the European communities (EC) at that time proclaimed the environment as important. However, in the subsequent half-century, the environment has become a prominent concern, which has also had an impact on international law. Although the main human rights instruments (the 1948 Universal Declaration of Human Rights, the 1950 European Convention on Human Rights, the 1961 European Social Charter, the 1966 International Covenants), all drafted well before a full awareness of environmental issues arose, do not refer to the environment, today it is commonly accepted that human rights and the environment are interrelated. Even to the point where it is suggested that environmental rights belong to a "third generation of human rights" (Council of Europe, 2012: 11; Vasak, 1977).

Since then, considerable steps have been taken; not only has the body of environmental and health legislation been developed, but public participation and public surveillance in environmental decision-making have increased as well. On the other hand, especially in the last two decades, following the huge industrial accidents (Seveso 1976, Bophal 1984, Černobil 1986), rules on the healthy living environment have been taken more seriously. The courts, not only the legislators, make strokes, sometimes also bold ones.

This article is based on the fact that environmental distress, such as various kinds of pollution of air, water, soil by the industry, traffic, different commercial activities, etc., causes health implications (Resnik et al., 2017) (the author, being a lawyer, does not discuss the viewpoints or discourses in this respect; for the purposes of this article, these scientific proofs are taken as a fact and are not even listed here). Namely, the article tries to explore legal consequences of health implications. To this respect, one should make a division between possible legal actions with ex post effect on the one hand and ex ante actions on the other hand. The latter applies for possibilities to regulate preventive measures in order for health implications to be minimised or not to occur; while the first one is applicable in the cases where health implications have already happened and the individual would like to claim the indemnity for the damage caused. Both approaches are discussed below.

There is a huge difference between both from the perspective of substantive law, as well as from procedural aspects. Furthermore, persons involved have different roles; 
in ex-post cases, only individuals who suffered damage are usually active, while in the ex-ante approach, different kinds of individuals are active; environmentalists, members of NGOs, individuals who care for others and for future generations. Ex ante actions are addressed to state authorities, like legislators or administrative authorities, while ex post actions are mostly addressed to the polluters; however, actions against the state are also possible. Only the main differences are described above, at the outset, but let us have a closer look from the perspective of the European (EU and beyond) rules.

\section{$2 \quad$ Ex ante obligation to secure a healthy living environment}

\subsection{Introduction}

In modern legal systems, constitutions, as well as international rules, obligations of states to secure a healthy living environment are usually present - at least in an abstract manner in the highest acts, like constitutions. The real question is, how farreaching these rules are and how they are interpreted. Until recently, these obligations were mostly understood only as a negative obligation, meaning that the state authorities are like a watchdog for possible violations by private parties, the industry. What was missing is a notion of positive obligation, meaning that the states, governments, and legislators, shall assure a healthy living environment - in advance; meaning that they have to adopt acts which shall secure a healthy living environment. Usually, the command-and-control approach is applicable; meaning that state authorities set out norms, values, standards to be obeyed. The question is, what if these standards and (emission) values are not sufficient. Namely, the state and its administration have controls over their own acts and, usually, they do not want to adopt and apply rules which they themselves cannot obey. This might be detrimental to the individuals, as well as the environment/nature. Or, as the ECJ had put forward in case C-404/13: »Where a Member State has not complied with the limit values and has not applied for a postponement of the deadline in accordance with the prescribed conditions, it is for the competent national court, should a case be brought before it, to take, with regard to the national authority, any necessary measure, such as an order in the appropriate terms, so that the authority establishes the plan required by the directive to ensure, in particular, that the period during which the limit values are exceeded is as short as possible «. This is a clear picture of how the power of the courts differs from the power (intentions) of the legislator and administrative authorities.

To this respect, international obligations, especially the above-listed conventions and, above all, the ECHR and Aarhus convention, forced states towards the theory of positive obligation. 
$R$. Knez: Legal aspects of health implications caused by environmental distress

\subsection{The framework of the ECHR}

The right to life is protected under Art. 2 of the Convention. This article does not solely concern deaths resulting directly from the actions of the agents of a state but also lays down a positive obligation on states to take appropriate steps to safeguard the lives of those within their jurisdiction. This means that public authorities have a duty to take steps to guarantee the rights of the ECHR even when they are threatened by other (private) persons or activities that are not directly connected with the state (Council of Europe, 2012: 18, L.C.B. v. the United Kingdom, judgment of 9 June 1998, paragraph 36; Paul and Audrey Edwards v. the United Kingdom, judgment of 14 March 2002, paragraph 54; Öneryıldız v. Turkey [GC], judgment of 30 November 2004, paragraph 71; Budayeva and Others v. Russia, paragraph 128). It must be stressed, however, that cases in which issues under Art. 2 have arisen are exceptional. So far, the Court has considered environmental issues in four cases brought under the said article, two of which relate to dangerous activities and two of which relate to natural disasters.

The ECtHR has found that the positive obligation on states may apply in the context of dangerous activities, such as nuclear tests, the operation of chemical factories with toxic emissions or waste collection sites, whether carried out by public authorities themselves or by private companies. In general, the extent of the obligations of public authorities depends on factors such as the harmfulness of the dangerous activities and the foreseeability of the risks to life (Öneryıldız v. Turkey [GC], paragraph 73; L.C.B. v. the United Kingdom, paragraphs 37-41).

In addition, the ECtHR requires states to discharge their positive obligation to prevent the loss of life also in cases of natural disasters, even though they are, as such, beyond human control, in contrast to the case of dangerous activities where states are required to hold ready appropriate warning and defence mechanisms (Budazeva and Others v. Russia, judgment of 22 March 2008, paragraph 135). In Budayeva and Others v. Russia, the ECtHR was asked to consider whether Russia had failed its positive obligation to warn the local population, to implement evacuation and emergency relief policies or, after the disaster, to carry out a judicial enquiry, despite the foreseeable threat to the lives of its inhabitants in this hazardous area. The application resulted from a severe mudslide after heavy rainfalls, which had cost numerous lives. The ECtHR also found that there had been a causal link between the serious administrative flaws in this case and the applicants' death (see also "T.M.C. Asser Instituut - ECHR”).

In the first place, public authorities may be required to take measures to prevent infringements of the right to life because of dangerous activities or natural disasters. This entails, above all, the primary duty of a state to put in place a legislative and administrative framework, which includes (Öneryıldız v. Turkey [GC], paragraph 90; Budayeva and Others v. Russia, paragraphs 129, 132): 
- making regulations which take into account the special features of a situation or an activity and the level of potential risk to life. In the case of dangerous activities this entails regulations that govern the licensing, setting-up, operation, security and supervision of such activities;

- placing particular emphasis on the public's right to information concerning such activities. In cases of natural disasters this includes the maintenance of an adequate defence and warning infrastructure;

- providing for appropriate procedures for identifying shortcomings in the technical processes concerned and errors committed by those responsible.

In the Öneryıldız and Budayeva the ECtHR stated that these tasks are the primary duty flowing from the positive obligation in Art. 2. The legislative and administrative framework should provide effective deterrence against threats to the right to life. Although this has previously been applied in the context of law enforcement, the significance is that in both these cases, the ECtHR transposed this principle to environmental hazards. In Öneryıldız the ECtHR applied it in the context of dangerous activities and in Budayeva it applied it to natural disasters.

Moreover, in the case of dangerous activities, the significance of the necessary legislative and administrative framework will usually require that the responsible public authorities make regulations concerning dangerous activities. In modern industrial societies (post-industrial risks) (see Nicolas de Sadeleer, 2005: 3-4) there will always be activities which are inherently risky. The ECtHR decided that regulation of such activities should make it compulsory for all those concerned to take practical measures to protect people whose lives might be endangered by the inherent risks (Council of Europe, 2012: 38).

The most significant difference between cases of natural disasters and dangerous activities is that the ECtHR tends to provide states with a broader margin of appreciation for the former due to their unforeseeable nature, which is beyond human control. Moreover, the ECtHR stated that the scope of positive obligations imputable to the state in the particular circumstances would depend on the origin of the threat and the extent to which one or the other risk is susceptible to mitigation. In the sphere of emergency relief, where the State is directly involved in the protection of human lives through the mitigation of natural hazards, these considerations should apply in so far as the circumstances of a particular case point to the imminence of a natural hazard that had been clearly identifiable, and especially where it concerned a recurring calamity affecting a distinct area developed for human habitation or use (Budayeva and Others v. Russia, paragraph 137). 


\subsection{The EU approach}

While different pollution in Europe has improved steadily over the last few decades, significant problems remain. Up to a third of Europeans living in cities are exposed to levels of pollution which exceed the limit values. It is estimated that exposure to air pollution is associated with 420,000 premature deaths in 2012, making it one of the biggest public health challenges faced in Europe. One of the main reasons for the failure of the legislation to adequately protect human health is that it is not properly enforced. Public and private bodies alike can breach pollution laws with impunity, safe in the knowledge that they are unlikely to face any significant penalties. The European Commission is responsible for enforcing compliance by EU member states but lacks the resources, political independence and the will to do so. However, individuals and NGOs are increasingly stepping in to fill this "enforcement gap", assisted by a series of rulings by the Court of Justice of the EU (CJEU) which have clarified the nature of both the rights conferred on EU citizens and the obligations imposed on national institutions by air pollution laws (Andrews, 2016: 30).

The right to clean air has its origins in this 1991 case, which concerned Germany's failure to comply with one of the first EU air quality directives, which laid down limit values for levels of lead in ambient air. The EU Court of Justice (ECJ) held that because the limit values were imposed specifically to protect human health, it meant that whenever they are exceeded, "persons concerned must be in a position to rely on mandatory rules in order to be able to assert their rights". This implied that people have access to the court to enforce their right to clean air (Case C-59/89 Commission v Germany [1991] ECR-I 2626, at paragraph 22). In the Janecek case (Case C-237/07 Janecek v Freistaat Bayern [2008] ECR I-6221 at paragraph 39) the ECJ basically enforced the positive obligation of the state as well as in the abovediscussed cases of Art. 2 of the ECHR. This idea, from the above case Commission v. Germany, lay largely dormant for 15 years until the Janecek case. Mr. Janecek was the resident of a highly-polluted street in Munich who took legal action in relation to breaches of the limit values for PM10 (for Slovene cases see "Sloveniji še en opomin zaradi slabe kakovosti zraka"). The case was eventually referred to the ECJ, which held that: "...natural or legal persons directly concerned by a risk that the limit values or alert thresholds may be exceeded must be in a position to require the competent authorities to draw up an action plan where such a risk exists, if necessary by bringing an action before the competent courts." ("Legal Actions for Clean Air: Lawsuits and Decisions").

This was a landmark ruling and one of the most important environmental cases in recent years. It established not only that citizens had the right to use court's decision to enforce limit values (the right of standing), but also the right to a plan (the right to a legal remedy) and the right to demand judicial scrutiny of that plan (the right to substantive review). Unfortunately, the ECJ held that such plans only had to ensure 
a gradual return to compliance with limit values. However, the Janecek case was not only significant in that it granted the right to clean air - it has significance well beyond the sphere of air quality. This is because it recognised that EU citizens had a right to access national courts to uphold EU laws which were in place to protect human health. Interestingly, this right did not derive from the Aarhus Convention, but from broader principles of EU law: namely that national courts must give effect to EU law rights by providing effective remedies (Andrews, 2014: 30). Nevertheless, Janecek case started several actions for clean air in the EU Member States ("Legal Actions for Clean Air: Lawsuits and Decisions").

In many ways, Europe is not only playing catch-up with the rest of the world in these matters but is doing better (diff. Andrews, 2016: 3). The US, while not normally celebrated as a paragon of virtue in environmental protection, was indeed a pioneer in tackling air and other pollutions. Especially the 1970 Clean Air Act introduced the concept of the "citizen attorney general": arming ordinary citizens with the right to go to court to enforce pollution laws when governments and regulators failed. In a series of cases brought by NGOs and activist lawyers beginning in the 1980s, the Indian Supreme Court has ordered the removal of diesel buses, vans, and taxis from the roads of Delhi. The appalling levels of pollution in Delhi show that there is still much work to be done if the right to breathe clean air is to become a reality there, but the situation would likely be even worse were it not for these cases (Andrews, 2016: 3). Even China has responded to its own "airpocalypse" by passing laws which confer rights to environmental information, public participation in environmental decision-making and the right of citizens and NGOs to go to court to enforce laws against polluting companies (although, unsurprisingly, these rights do not extend to breaches of the law by the state) (Andrews, 2016: 3).

\section{Ex post actions regarding healthy living environment}

\subsection{The framework of the ECHR}

Another important rule of the ECHR (besides the above-discussed Art. 2) is Art. 8, and it is better to place it under ex post cases (namely, positive obligations of the states are mostly judged under Art. 2, not under Art. 8). Art. 8 concerns the right to respect for private and family life and the home. This right implies respect for the quality of private life as well as the enjoyment of the amenities of one's home ("living space") (Powell \& Rayner v. the United Kingdom, judgment of 21 February 1990, paragraph 40). Although there is no word mentioning the environment, distress, pollution etc., this rule also serves these purposes. The ECtHR also extended its aim to the environmental distress, which produces effects on individuals. In a number of cases, the ECtHR has found that severe environmental pollution can affect people's well-being and prevent them from enjoying their homes to such an extent that their rights under Art. 8 are violated. 
According to the ECtHR, the right to respect for the home does not only include the right to the actual physical area but also to the quiet enjoyment of this area within reasonable limits. Therefore, breaches of this right are not necessarily confined to obvious interferences such as an unauthorised entry into a person's home, but may also result from intangible sources such as noise, emissions, smells or other similar forms of interference (Moreno Gómez v. Spain, judgment of 16 November 2004, paragraph 53; Borysiewicz v. Poland, judgment of 1 July 2008, paragraph 48; Giacomelli v. Italy, judgment of 2 November 2006, paragraph 76; Hatton and Others v. the United Kingdom [GC], judgment of 8 July 2003, paragraph 96; Deés v. Hungary, judgment of 9 November 2010, paragraph 21). If such interferences prevent a person from enjoying the amenities of this home that person's right to respect for his home may be breached. In the context of cases raising issues linked to environmental degradation or nuisance the Court has tended to interpret the notions of private and family life and home as being closely interconnected (Imparato, 2015: 129).

However, the ECtHR's position differs when adjudicating on the environment protection on the one hand and the human rights that refer to the environment on the other; thus, it claimed in Kyrtatos v. Greece (judgment of 22 May 2003), that domestic legislation and certain other international instruments rather than the ECHR are more appropriate to deal with the general protection of the environment (the dispute was about the swamp because of which the claimant's property lost its scenic beauty). The purpose of the ECHR is to protect individual human rights, such as the right to respect for the home, rather than the general aspirations or needs of the community considered as a whole (the environment as such).

On the other hand, the Court has found that "severe environmental pollution" such as excessive noise levels generated by an airport, fumes, smells and contamination emanating from a waste treatment plant and toxic emissions from a factory can interfere with a person's peaceful enjoyment of a home, even when the pollution is not seriously health-threatening (cases like Hatton and Others v. the United Kingdom [GC], López Ostra v. Spain, judgment of 9 December 1994; Guerra and Others v. Italy [GC], judgment of 19 February 1998; Tătar v. Romania, judgment of 27 January 2009 (in French only); Ledyayeva and Others v. Russia, judgment of 26 October 2006, Fadeyeva v. Russia and Taşkın and Others v. Turkey, judgment of 10 November 2004, paragraph 113; Ioan Marchiş and Others v. Romania, paragraph 28).

For instance, in the López Ostra (judgment of 9 December 1994), the applicant complained that the fumes and noise from a waste treatment plant situated near her home made her family's living conditions unbearable. The national authorities, while recognising that the noise and smells had a negative effect on the applicant's quality of life, argued that they did not constitute a grave health risk and that they did not reach a level of severity breaching the applicant's fundamental rights. 
However, the ECtHR found that severe environmental pollution might affect individuals' well-being and prevent them from enjoying their homes in such a way as to affect adversely their private and family life, even though it does not seriously endanger their health.

\section{$4 \quad$ Important issues - causal link and damages}

Although, as seen so far, the ECHR, as it is being interpreted (expanded) by the ECtHR, can offer "safety net" for all the national legislation and actual cases where the environmental distress has health implications for individuals (Berry, Bowen \& Kjellstrom, 2010: 123-132), it cannot be seen as an omnipotent solution.

The case Tătar v. Romania (above) offers the insight into the problem. In this case, the applicants, who lived near a gold ore extraction plant, had lodged several complaints with the authorities about the risks to which they were being exposed because of the use by the company of a technical procedure involving sodium cyanide. In 2000, despite the fact that the authorities had reassured the applicant that sufficient safety mechanisms existed, a large quantity of polluted water spilled into various rivers, crossing several borders and affecting the environment of several countries. In this particular case, on the one hand, the ECtHR was confronted with the problem that there was no internal decision or other official document stating explicitly how much of a threat the company's activities posed to human health and the environment and on the other hand, the ECtHR found that the applicants had failed to prove that there was a sufficient causal link between the pollution caused and the worsening of their symptoms.

Since the ECtHR did not consider a causal link to be present between the health deterioration of Tătar junior and the pollution, no damages whatsoever were awarded. On this point judges Zupančič and Gyulumyan dissented. Their partial dissent offers an intriguing critique of a rigid adherence to classical causal thinking, as opposed to more modern probabilistic theories. In these cases of exposure to toxic materials, the dissenting judges stated that absolute causality is almost impossible to prove in practice (Buyse, 2009). The causality is being more problematic than the scope of damages. Namely, the (immaterial) damage to individuals can be assessed, if not otherwise, with the help of health implications from other reasons, like accidents etc. The real and sophisticated problem in the connection between the environmental distress and health implications is the one of a casual link.

The mentioned case Tătar and a dissenting opinion of the judges clarify the picture; they disagreed with the conservative approach taken by the court with respect to causality. They started their argumentation with the viewpoint of sociologists who stress that the approach to the causality is overly precautious (in favour to the polluters) and that this is a strong characteristic which should be abandoned as it is contrary to the mentality of civilised temporary development. Namely, most effects will be caused by different factors. The factors are multiple. Basically, there are no 
clear cases. It is impossible to prove that a certain illness of a certain individual who has been exposed to a certain toxic source is in total causality. What is possible is that a certain statistical significance is taken into account that shall reflect different results with respect to the population which was exposed to a certain toxic source and the population which was not. They offered an example; it is almost impossible to prove with a certain certitude that lung cancer cannot be proven scientifically for certain causes, but there is a statistical data that $92 \%$ persons who smoke get a lung cancer. In their opinion, this should suffice. They also argued that certain effects of dangerous activities cannot be seen immediately, but they can be visible after a long period of time. The reason can also be contributed to a certain list of factors and not to the unique source. It is quite clear that certain pathologists of the contemporary era do not have the so-called signature of "de l'agent causal" (i.e. one source only). They cited a case from French jurisdiction where the Appellate court in Versailles adjudicated on the responsibility of one laboratory for their product (vaccine) (CA Versailles, 30 Avril 2004, D 2004, IR p. 1502). Their decision was based on statistical data. The court was of the opinion that it would be difficult for such illness to occur without the vaccination. Of course, also according to their opinion, it is necessary to take into account the uncertainty of the statistics; therefore, the judges should, after the consultation with experts, take into account the statistical deviation (Tătar v. Roumanie of 27.1.2009, dissenting opinion of both judges). It is to be added that the question of causality remains relevant in the case of a strict liability regime as well. In both, in a fault-based, as well as in a strict liability regime, the casual link shall be established.

There is another problem with new contemporary risks; the so-called post-industrial risks (Nicolas de Sadeleer, 2015: 3-4). In the case of post-industrial risks, it is impossible to reach a decision based on scientific and statistical data. However, this is not a direct excuse for the court to decide that it is not possible to conclude that certain illness is not in causality with certain activities/products. Even more, certain modern industries usually use substances which are difficult to prove; also difficult to establish are certain effects like illness of cancer or certain carcinogenic substances which mutate, for instance. Again, certain substances can penetrate into the human body not only by inhalation but also through the skin, eyes, with food, etc. All these elements shall be taken into account and would lead the court to establish that the presence of one main circumstance in a combination (or in the absence) of other causes can establish a causality which is sufficiently probable. Basically, in the cases of the existence of a probability, the emphasis should be given to the negative approach, in the sense that the presumption of certain causes is abandoned, and vice versa. In the second step, the court should consider whether certain effect can happen in the present environment of the individual. It is necessary to establish/assess the correlations. The court shall take into account that certain proofs are almost impossible or totally impossible to be performed (probation diabolica). Moreover, the absence of necessary information can give rise to this situation. In cases where the information is absent, the negative effects of 
that fact should not be a burden for the individual; this is the question of the equality of arms in the judicial procedure (Tătar v. Roumanie of 27.1.2009, dissenting opinion of both judges). Namely, how can the individual prove causes that are in the sphere of the polluters? Indeed, a different approach is necessary for a postindustrial risk.

It is also important, as the judges Zupančič and Gyulumyan emphasised in this dissenting opinion, that it is necessary to take into account the presence of risks which are invisible and to which the classical causality cannot be applied; the classical causality represents an "archaise"; in a formal treatment of causality, under the inquisitorial system, the fault shall be absolutely attributed as a burden of proof to one party. The burden, which is attributable to the parties, is not always appropriate. In real life, as the judges stated, the fetishisation «? (a strange word derived from fetish) of the causality is a product of a need for the judges to discreetly distribute the fault between the parties. However, the judicial process, in which the truth shall be sought in order to resolve the conflict, should not strive to deny the perception of the reality.

In other words, the scientific objectives sometimes cannot serve the parties. There are different nuances in the cases, especially in the cases with post-industrial risks. A special medical and a legal science often do not speak the same language; judges search for black and white answers of medical experts, which they cannot offer (Tătar v. Roumanie of 27.1.2009, dissenting opinion of both judges). Therefore, a search for the absolute causality is not appropriate. If continued that way, the inequality of arms will be in favour of the polluters (one might say the capital).

So far, at least to my knowledge, this is the most clear-cut opinion of the ECtHR judges. Unfortunately, this is not part of the judgment; it is a dissenting opinion (only). However, it remains to be seen whether the ECtHR will follow this path or not.

The latter can be said for the latest jurisprudence in Slovenia; in 2016, the judges of the Appellate court in Ljubljana made, in my opinion, a huge progress towards this kind of reasoning. The case (III P 483/1995 of 9 May 2016) indeed did not concern health implications but rather losses of the property; the plaintiffs were farmers, suing several companies in Zasavje for the loss of profit in agricultural products. The case lasted for 18 years. The main issue was a causality. The court took a stand that it is improper to search for a full causality. It (p. 12) contemplated that the plaintiffs shall have the burden of proof, but only for a minimum scope of those facts that are necessary for the conclusion (i.e. legal consequence, the so-called constitutive facts). This does not consider all circumstances of the case. The plaintiffs could not have known what the defendants have emitted in the air. If the plaintiffs cannot know legally relevant facts, it suffices if even general or assumed facts are given by the plaintiffs. This is a very important viewpoint. Especially if 
certain facts are relevant but are outside the plaintiffs' sphere, the burden of proof shall be weakened.

The appellate court reiterated that plaintiffs in that case have put forward all known facts from their side, which were specified enough so that the defendant would have known how to construct their defence. Further on, under the point 20 of the judgement, the court was of the opinion that division of the burden of proof among the parties is not static and defined in advance. It also shall be taken into account that certain facts are not known to the plaintiff and that can be resolved only by the experts during the proceeding.

If one compares this judgement with the one from 1994, in which the Supreme court of the RS had to decide whether the thermoelectric plant in Šoštanj is liable for damage caused in the forests (due to the SO2, decision III Ips 9/94 of 12 May 1994, in connection with the decision of the Appellate Court in Celje VSC Cpg 128/93), the rhetoric of the court reasoning in the Zasavje judgement is rather different; the polluter-based principle in the latter judgement from 2016 (Zasavje) is much more in line with the modern approach. However, as emphasised, especially the causality is understood much more in line with the dissenting opinion of the judges in case Tătar v. Roumanie. This is also in line with the principle of proportionality, under which the courts shall assess the adequacy, not only the legality. In other words, even if the burden of proof currently enacted is legal, it might, depending on the case, not be adequate. The principle of proportionality, included in the rule of law principle, can give courts a necessary margin to handle the burden of proof in line with the above-described discussion.

It remains to be seen whether this approach will be followed in the future. In order to be a witness to the future path, it is necessary that individuals bring actions to the court. In Slovenia, there are several possible cases, for instance, the pollution in Celje valley with heavy metals from industry (see "Poročilo, ki je šokiralo celo vodstvo"). Court lawsuits seem inevitable; in fact, in only one (class) case thus far did the state legislator react positively in favour of the injured parties (by way of adopting a statute). This was in the case of workers using the dangerous asbestos. The lex specialis statute (Act Concerning Remedying the Consequences of Work with Asbestos, OJ of the RS, Nr. 51/09) was adopted. The injured individuals were able to receive compensation (in most cases for the lung cancer). The statute dates from 2006 and in the last decade (or even before) there are no such approaches. They would also not be consistent with the polluter pays principle, since the costs in such a case (legislative action) would be socialised and not internalised by the polluter. 


\section{The role of the NGOs}

NGOs are extremely important, sometimes being the only activist against improper state/polluter activities/acts. Usually, the NGOs will be more successful in challenging general acts or legislative acts as well as acts of administrative authorities of general application. As a rule, individuals will have much fewer chances regarding locus standi. On the other hand, when it comes to damages, individuals will be successful with locus standi and access to the court. However, their problem will be a substantive one - that is, to prove the causality and damages, especially when it comes to non-material damages, as it is the case with health problems. Another difference between NGOs and individuals is also that individuals can file claims only to pursue their own rights (as it stems from German theory individualrechtsschutz). This means that claims will be individually oriented and might not have any discouraging effect towards the polluter. Class actions would, in this respect, bring certain advantages. However, the proposal for European Union rules on collective actions in case of the environment has stopped with redress principles which are to be followed by national rules (see "Judicial Redress - Collective Redress - European Commission"; "Legal Actions for Clean Air: Lawsuits and Decisions").

In this respect, when defending general interests of the environment and corollary of the healthy living environment for the individuals, the NGOs can be more successful. Quite some cases were successful in the last decade, also at the EU level; firstly, because NGOs succeeded to gain locus standi with the help of Aarhus convention and, secondly, because they gained the access to legislative procedures or procedures of administrative authorities and thirdly, because they influenced the procedures and affected the outcomes. Nowadays, they (as well as the individuals) also bring important lawsuits for future generations (in the USA and the EU).

A role of NGOs being active in the field of the environment is important since they represent the environment/nature, which are not able to defend their rights in any administrative, civil or criminal procedure by themselves. Usually, one of the main issues is whether certain NGO has standing (locus standi) in procedures defending the interests of the environment and with this also our, i.e. public interest. So far, we are used to researching and analysing court cases also under the Aarhus convention, focusing on the issue of locus standi. However, the damages, especially the non-material or moral damages, as a separate kind, are not very likely to be awarded.

However, since the damages (whichever kind) do also have the preventive effect, this issue might indeed be very important. To this effect, it is worth analysing whether NGOs are entitled to be awarded different kinds of damages in case the state or the investor do not comply with the environmental rules. This shall indicate further pressure on polluters. It is not the NGO who actually suffers the damage, but the environment. However, this starting point might not be true in the case of 
moral damages. A recent decision of the Belgium Constitutional court $\left(\mathrm{N}^{\circ} 7 / 2016\right.$, 21 January 2016, Vogelbescherming Vlaanderen and Terre Wallonne, based also on the Aarhus Convention Art. 9, paras. 3 and 4) can serve as a beacon. In this case, explained bellow, the Belgian Constitutional court awarded moral damages to an NGO. This is important because NGOs can be, as noted above, the leading subjects forcing the polluters on the one hand and states on the other to change the attitude towards the healthy living environment.

In a criminal case pending before the Criminal Court of East Flanders, Ghent Division, concerning illegal hunting practices, a bird protection organisation (Vogelbescherming Vlaanderen) acted as a civil party on the basis of the case law of the Belgian Supreme Court (see PP and PSLV v. Gewestelijk Stedenbouwkundig Inspecteur and $\mathrm{M}$ vzw), claiming 1.900,00 euro for material and moral damages.

According to the Supreme Court's case law, it is impossible to award the bird protection organisation a sum per bird killed, as they belong to no one. Furthermore, in the absence of statutory law, the moral damage of an environmental NGO can only be compensated symbolically by awarding 1 euro compensation. Vogel bescherming Vlaanderen argued that this case law discriminated against environmental NGOs in comparison with other legal and natural persons since such parties are entitled to receive full compensation for the moral damage suffered. The Criminal Court referred that constitutional issue to the Constitutional Court for a preliminary ruling. The Constitutional Court reached the conclusion that the provision of the Civil Code (Art. 1382) concerning fault-based liability is violating Arts. 10 and 11 of the Constitution if interpreted in such a way that Environmental NGOs can only claim one symbolic euro as a compensation for moral damages. The Court argued that the moral disadvantage an environmental NGO may suffer due to the degradation of the collective interest in the defence of which it is established is, in several respects, special.

In the first place, that disadvantage does not coincide with the ecological damage caused, since ecological damage constitutes damage to nature, meaning that the whole of society is harmed. The damage concerns goods such as wildlife, water, and air, belonging to the category of res nullius or res communes.

Furthermore, the damage to non-appropriated environmental components can as a rule not be estimated with mathematical precision, because it involves noneconomic losses. In terms of the rules governing civil liability, judges must assess the damage in concreto and they may base it on equity if there are no other means to determine it.

The compensation must, as far as possible, reflect reality even in the case of moral damage. It should be possible that in the case of moral damage to an environmental NGO, the judge can estimate the damage in concreto. In these circumstances, s/he 
should take into consideration the statutory objectives of the NGO, the extent of its activities, its efforts to realise its objectives and the seriousness of the environmental damage at stake. Limiting the moral damage to one symbolic euro is in that respect not justified. It would disproportionality harm the interests of environmental NGOs that play an important role in guaranteeing the constitutional right of the protection of the environment. Therefore, the Constitutional Court promoted another interpretation, concluding that "Article 1382 of the Civil Code does not infringe Arts. 10 and 11 of the Constitution, whether or not read in conjunction with Arts. 23 and 27 of the Constitution and Art. 1 of the First Additional Protocol of the ECHR in that the interpretation does not preclude the granting to a legal entity pursuing a collective interest, such as the protection of the environment or specific components of it, of compensation for moral damages to that collective interest, that goes beyond the symbolic sum of one euro." This interpretation, which is consistent with the Constitution, is binding for the referring judge and in fact also for other judges charged with ruling on similar cases.

The judgement should put an end to different approaches taken in case law. In fact, there are already some past examples of Belgian courts awarding full compensation for moral damages to environmental NGOs (see e.g. CITES crimes - Court of Appeal, Ghent, 7 May 2015). This is a nice example of additional pressure on all those who harm the nature and the environment and a shift towards the ethical appraisal of the environment, not only the legal one. It could be considered a kind of Copernicus' revolution (together with the lawsuits for future generations), helping primarily in administrative and criminal law procedures in which the environment is at stake. Since the protection of the environment has a huge public support, the ethical judgment can have a certain effect. I am fully aware that awarding moral damages is not an ethical judgment, but it is close to that. I am quite sure that the court did not stop, when deciding the above case, only with legal reasoning, but that the reasoning was broader, reaching elements beyond the pure law, i. e. elements of ethics, and including the message of moral judgment to the public.

\section{Conclusions}

In the last 50 years, in the human lifetime, the environment has been changed dramatically. We have succeeded in destroying the balance essential to life and a healthy living environment in only approximately 50 years, in a single human lifetime. The environment has been changed more radically than by all previous generations of humankind. No prior generation had caused so many negative changes to the human living environment as the baby boom generation.

The legislators, as well as international community, made this possible. The legislators were not brave enough in the past decades, and decisions they issued were not in line with the legitimate claims of individuals and advanced thinking individuals. This is, to a large extent, still true today (for instance, the case of TEŠ 
and Block VI in Šoštanj, Design \&, Environmental, and Department of Design and Environmental Analysis, etc). Changes in the environment are also causing health implications for humans, either with risks which are known, visible and immediate or with causes which can only be seen over a long period (delayed consequences) or can even be hardly scientifically proven.

Reactions to minimise and to prevent the negative effects and health implications for humans have started in 1980's with the troika of industrial accidents (Seveso, Bobhal, Chernobil). Almost at the same time, the EC (at that time) legislator and ECJ proclaimed the environmental protection and human health as a goal of the EC (at that time). This was the start of a long lasting process, still on-going, which faces significant obstacles. Later, the ECtHR also expanded Arts. 2 and 8 to the environment and to human private life (health). The two mainstreams are clearly visible for both international players: first, there is a positive obligation of Member States to actively prevent negative effects of human activities, mostly industrial activities, and second, the ex post claims of individuals if such implications happened.

Claims for damages are not in the foreground when it comes to health implications since they cannot cure them, but only offer a compensation. It is a kind of secondary protection. Still, damages also have important preventive effects. And claiming damages made it possible for the courts, which sometimes indeed acted in an activist manner (which also depends on the judge as an individual, and, importantly, the judges shall not be lobbied in the same way as legislative authorities), to develop important principles (like precautionary principle; see in this respect the case C352/98 P. Bergaderm). Claims for damages are usually, differently than in the ex ante approach, the main force with which individuals influence legislators through the courts.

It is, of course, possible to directly pressure the legislators, but this option is less powerful, and in this respect, NGOs can be more successful. Real threats to polluters and to the state that enables environmental distress can indicate private actions for damages. For several reasons, they are not well developed in Europe in comparison to the USA; they have not been historically present in European legal culture and, therefore, the individual's claims for damages are not massive. Furthermore, it is far from easy to prove a causal link and damages. In this respect, especially when it comes to post-industrial risks (which are even scientifically difficult to prove), the courts should change the approach towards a more lenient theory of causality, making legal claims against polluters/state more in line with real-life problems.

Nowadays, the still applicable theories of causality, being developed decades ago under completely different circumstances, are far from the real-life and post/industrial risk elements. In this respect, the dissenting opinion in the case Tătar shall be taken much more seriously. The signs indicate that national courts are 
following this streamline as well (the latest one in Slovenia in 2016, mentioned above). This should encourage private actions, discouraging those who would, due to their (dangerous) activity, cause environmental distress and negative health implications for individuals. The courts, although traditionally conservative, are showing positive attitude towards this streamline (sometimes more so than state authorities, but being influenced by these developments, NGOs pressuring, and stricter environmental standards of international community, the state authorities are also changing legislation towards stricter rules, and the overall picture is very different than two or three decades ago).

These rather positive conclusions of developments do not mean that the job is done; we are still facing industrial and other activities or products that have substantive negative implications for human health (for instance ' $L$ 'eau du robinet de près de trois millions de consommateurs est polluée"); however, the path towards their prevention (directly ex ante or indirectly ex post) has changed. Furthermore, the tendency is still present today to provide relief to the economic value, not to the value of health (Imparato, 2015: 134).

The pressure of the international community, NGOs, as well as individuals in private actions and the pressure maintained by the courts have consequentially lead to the improved situation and better awareness. After decades of developments predominantly favouring economic prosperity, certain discouraging effects for (dangerous) activities and its industry were necessary (not only for the present but also for the future generation). The awareness of the negative health implications is to be taken much more seriously. The jurisprudence of ECtHR and ECJ, although not always consistent, nevertheless serves as a beacon of standards to follow.

\section{References}

Andrews A. (2016) Upholding the right to clean air in the courts : editorial, Clean Air Journal, 26(2), pp. 2-3, doi: 10.17159/2410-972X/2016/v26n2a1.

Andrews A. (2015) The Clean Air Handbook - A Practical Guide to EU Air Quality Law, available at: http://www.clientearth.org/reports/20140515-clientearth-air-pollutionclean-air-handbook.pdf (January 14, 2017).

Asser Institute (2013) T.M.C. Asser Institute - ECHR, available at: http://www.asser.nl/eel/case-law/echr/echr-environment-cases/ (January 15, 2017).

Berry, H. L., Bowenand, K. \& Kjellstrom, T. Climate Change and Mental Health: A Causal Pathways Framework, available at: https://www.researchgate.net/profile/Helen_Berry4/publication/40768724_Climate_cha nge_and_mental_health_A_causal_pathways_framework/links/0046351883caa3766a00 0000.pdf (December 31, 2016).

Buyse A. (2009) Environmental Pollution Judgment (Tătar v. Romania, judgment of 27 January 2009 (in French only), available at: http://echrblog.blogspot.si/2009/01/environmental-pollution-judgment.html (February 17, 2017). 
Council of Europe (2012) Manual on human rights and the environment (Council of Europe Publishing).

Clean Air (2017) Lawsuits and decisions, available at: http://legal.cleanaireurope.org/legal/germany/lawsuits-and-decisions/ (January 15, 2017)

Clean Air (2017) Legal Actions for Clean Air: Lawsuits and Decisions, available at: http://legal.cleanair-europe.org/legal/germany/lawsuits-and-decisions/ (January 14, 2017).

Design \& Environmental and Department of Design and Environmental Analysis (n.a) How Natural and Built Environments Impact Human Health, available at: http://www.human.cornell.edu/outreach/upload/CHE_DEA_NaturalEnvironments.pdf (December 31, 2016).

de Sadeleer, N. (2005) Environmental Principles - From Political Slogans to Legal Rules (Oxford: Oxford University Press).

European Commission (2013) Judicial Redress - Collective Redress - European Commission, available

http://ec.europa.eu/consumers/solving_consumer_disputes/judicial_redress/index_en.ht m (February 21, 2017).

Imparato, E. A. (2015) The right to life passes through the right to a healthy environment: jurisprudence in comparison, Widener Law Review, 22, pp. 123-134.

Le Monde (2017) L'eau du robinet de près de trois millions de consommateurs est polluée, Le Monde, fr 26 Jan. 2017.

24ur.com (2017) Poročilo, ki je šokiralo velo vodstvo: Pod Cinkarno Celje plast nevarnih starih odpadkov, 24ur.com, available at: http://www.24ur.com/novice/slovenija/porocilo-ki-je-sokiralo-celo-vodstvo-podcinkarno-celje-plast-nevarnih-starih-odpadkov.html (January 15, 2017).

Resnik, D. B. (2017) Environment, Ethics, and Human Health. The Hastings Center. N.p., 23 Sept. 2015, availbale at: http://www.thehastingscenter.org/briefingbook/environmental-health/ (January 2, 2017).

Vasak K. (1977) Human Rights: A Thirty-Year Struggle: the Sustained Efforts to give Force of law to the Universal Declaration of Human Rights, UNESCO Courier 30:11 (Paris: United Nations Educational, Scientific, and Cultural Organization).

\section{Cases}

ECJ - Case C-237/07 Janecek v Freistaat Bayern [2008] ECR I-6221

ECJ - C-404/13 The Queen, on the application of ClientEarth v The Secretary of State for the Environment, Food and Rural Affairs

ECJ - C-352/98 P, Bergaderm, ECR 2000. p. I-05291

ECJ - Case C-59/89 Commission v Germany [1991] ECR-I 2626

ECtHR - L.C.B. v. the United Kingdom, judgment of 9 June 1998

ECtHR - Paul and Audrey Edwards v. the United Kingdom, judgment of 14 March 2002

ECtHR - Öneryıldız v. Turkey [GC], judgment of 30 November 2004

ECtHR - Budazeva and Others v. Russia, judgment of 22 March 2008

ECtHR - Moreno Gómez v. Spain, judgment of 16 November 2004

ECtHR - Borysiewicz v. Poland, judgment of 1 July 2008

ECtHR - Giacomelli v. Italy, judgment of 2 November 2006

ECtHR - Hatton and Others v. the United Kingdom [GC], judgment of 8 July 2003

ECtHR - Deés v. Hungary, judgment of 9 November 2010

ECtHR - Kyrtatos v. Greece, judgment of 22 May 2003 
ECtHR - Hatton and Others v. the United Kingdom [GC]

ECtHR - Ostra v. Spain, judgment of 9 December 1994

ECtHR - Guerra and Others v. Italy [GC], judgment of 19 February 1998

ECtHR - Ledyayeva and Others v. Russia, judgment of 26 October 2006

ECtHR - Fadeyeva v. Russia and Taşkın and Others v. Turkey, judgment of 10 November 2004

ECtHR - Tătar v. Romania, judgment of 27 January 2009 (in French only)

Slovenia - Case Appelate Court (Ljubljana) III P 483/1995 of 9 May 2016

Slovenia - Decision of te Supreme Court of the RS decision III Ips 9/94 of 12.5.1994

Belgium - Constitutional court, N 7/2016, 21 January 2016, Vogelbescherming Vlaanderen and Terre Wallonne

Belgium - PP and PSLV v. Gewestelijk Stedenbouwkundig Inspecteur and M vzw, Belgian Supreme Court

Netherlands - CITES crimes - Court of Appeal, Ghent, 7 May 2015

France - CA Versailles, 30 Avril 2004, D 2004, IR p.1502 
